
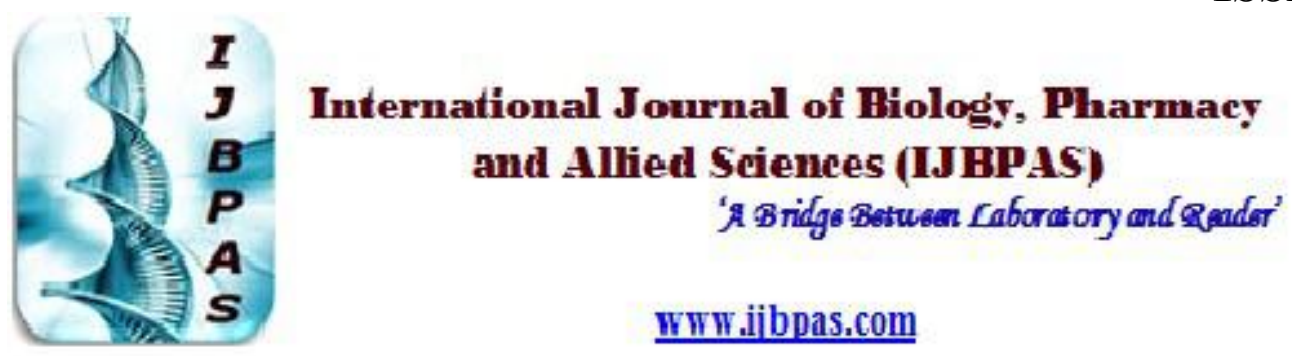

WWW.jibpas,com

\title{
Dillenia philippinensis, AN ILONGOT ETHNOBOTANICAL OF AURORA, PHILIPPINES SHOWS ANTIDIABETIC ACTIVITY
}

\section{MARY GRACE B. ANGELES, CYNTHIA C. DIVINA AND KHRISTINA G. JUDAN CRUZ $^{*}$}

Department of Biological Sciences, Central Luzon State University, Science City of Muñoz, Nueva Ecija, Philippines

*Corresponding author: Khristina G. Judan Cruz E-mail: karenjudancruz@gmail.com

Received 28 ${ }^{\text {th }}$ Feb. 2018; Revised 31 ${ }^{\text {st }}$ March. 2018; Accepted 24 ${ }^{\text {th }}$ April 2018; Available online $1^{\text {st }}$ July 2018

\section{https://doi.org/10.31032/IJBPAS/2018/7.7.4494}

\section{ABSTRACT}

Three plants with claims of antidiabetic potential: Dillenia philippinensis (katmon bark), Codiaeum variegatum (San Francisco) and Hydrocotyle vulgaris (Gutokola) were tested for their antidiabetic potential on lowering the blood glucose level in alloxan-induced diabetic mice.

D. philippinensis (Katmon Bark) effectively lowered the blood glucose levels of diabetic mice. Upon oral administration of the extract $D$. philippinensis, the blood glucose level had lowered by $15.92 \%$ at $30 \mathrm{mins}, 5.57 \%$ at $120 \mathrm{mins}$ and $12.43 \% 24$ hours post treatment administration with significantly comparable values on the positive control (glibenclamide) with percentage mean values lowered by $4.88 \%$ at 30 mins, $15.5 \%$ at 120 mins and $5.8 \%$ at 24 hours respectively.

Keywords: alloxan-induced diabetic mice, blood glucose level, Dillenia philippinensis

\section{INTRODUCTION}

Management of diabetes continues to be a challenge to the medical community [1]. Studies have shown that due to the inherent side effects of common oral hypoglycemic synthetic drugs, researchers are now intensifying efforts on alternative and complementary medicines to proffer lasting solution or at least control some harmful effects of synthetic drugs[2]. Choosing specific antihyperglycemic agent is predicated on their effectiveness in lo- 
wering blood glucose, extra glycemic effects that may reduce long-term complications, as well as issues on safety, tolerability, and expense [3].

The Philippines holds a high number of medicinal plant species entailing a broader scope for healing. However, with further economic development, there is rapid disappearance of traditional culture and natural resource[4]. Various plants have been traditionally used throughout history to reduce blood glucose and improve diabetes and its complications despite insufficient scientific information[5]. Although several herbal drugs, in spite their pronounced folkloric activity and known for having anti-diabetic property and their therapeutic evidence within the traditional healthcare system are reliable, most have not been formulated as drugs [6].

Ethnobotanical information indicates that more than 1,200 species of plants are identified as having hypoglycemic activity [7]. These medicinal plants are used to treat hypoglycemic or hyperglycemic conditions that are of considerable interest for ethnobotanical community as they are recognized to contain valuable medicinal properties with large numbers showing varying degrees of hypoglycemic and anti-hyperglycemic activity [8]. Sev- eral studies were done, however, studies on the ethnobotanicals from the IlongotEǵongot community of Bayanihan, Maria Aurora, Aurora are still limited. This study generally highlights the antidiabetic potential of Dillenia philippinensis.

\section{MATERIALS AND METHODS}

\section{Collection of Plant Samples}

Three ethnobotanical plants previously surveyed [9] with the permission of elders and barangay officials were used in the in vivo testing for its antidiabetic potential, these were: Codieum variegatum leaves, Dillenia philippinensis bark and Hydrocotyle vulgaris leaves. Plant samples were collected in Bayanihan, Maria Aurora, Aurora.

\section{Extraction Procedure}

The collected plant samples were washed using distilled water and placed separately into clean plastic bags. These samples were air-dried for 5-7 days at room temperature until it was pulverized and stored in a resealable plastic bag. The pulverized plant samples weighing 20 grams were extracted in $600 \mathrm{ml}$ distilled water in $80-90^{\circ} \mathrm{C}$ water for two hours. The extracted plant samples were lyophilized for 72 hours and refrigerated. 


\section{Preparation and Handling of Test Mice}

Tests were done on animals following the Institutional Animal Care and Use Committee (IACUC) policies, procedures and guidelines [10]. Male mice weighing 20-22 grams male mice aged eight weeks or older were used and provided with ad libitum standard mice pellet diet and distilled water. Experimental animals were conditioned and housed in an air-conditioned room with normal 12 hours day and night cycle. The mice were divided into five groups containing five mice each in improvised polypropylene cages.

\section{Induction of Diabetes to Experimental} Mice

Diabetes was induced via intraperitoneal injection of alloxan-monohydrate with $150 \mathrm{mg} / \mathrm{kg} \mathrm{b.w}$. dosage [11]. Induction was made to overnight fasted animals (8-12 hours fasting period) with access to water[12]. After the induction, animals were given $5 \%$ sucrose solution to overcome the induced hypoglycemia[13]. After 72 hours, diabetic state were verified and mice with blood glucose level above 250 $\mathrm{mg} / \mathrm{dl}$ were declared as diabetic and used in the study.

Oral Induction and Treatment

Administration
The treatments were taken orally with the aid of an improvised gavage according to their treatment designation. Two controls were used: the negative diabetic control treated with physiological saline, and the positive diabetic control treated with standard antidiabetic drug Glibenclamide at an oral dose of $3 \mathrm{mg} / \mathrm{kg}$ body weight. Three groups constituted the mice treated with designated lyophilized ethnobotanical extracts with a selected dose of $200 \mathrm{mg} / \mathrm{kg}$ body weight dissolved in a $1 \%$ concentration. All mice were treated with a $0.1 \mathrm{ml}$ dosage with saline solution as the diluent for the administration [14] [15] [16].

\section{Glucose Monitoring of Blood}

Blood samples were withdrawn from the animals by gently cutting a small portion of the tail tip of the diabetic mice. The tips of the tail were sterilized by swabbing with $70 \%$ ethanol after the operation. Test mice were bled according to the selected time frame of 0 hour or the baseline blood glucose level value and for every 30 mins, 120 mins, and 24 hours upon treatment. Blood glucose levels were recorded in $\mathrm{mg} / \mathrm{dl}$.

\section{RESULTS AND DISCUSSION}

The results revealed that the blood glucose level $(\mathrm{mg} / \mathrm{dl})$ among treatment means recorded at 30 mins, 120 mins and 
24 hours after treatment administration showed to have significant differences among groups at $<0.05$ level of significant (Table 1). The mean change in the blood glucose level recorded after 30 mins revealed that the positive control (glibenclamide) and the extract of $D$. philippinensis were statistically comparable on lowering the blood glucose level in diabetic mice. The negative control (saline), as well as the treatment consisting the extracts of C. variegatum and $H$. vulgarisare significantly different to the positive control at the same observation period.

Furthermore, at 120 mins and 24 hours observation period, it can be noticed that the extract D. philippinensis still appeared to be statistically equal with the mean change in the blood glucose level of the positive control (glibenclamide) having its consistent effectivity on the lowering of the blood glucose level.

Figure 1 shows the mean percentage change in the blood glucose level recorded from the initial or the baseline blood glucose value and after the treatment administration recorded at $30 \mathrm{mins}, 120 \mathrm{mins}$ and 24 hours. The graph depicts the percentage change in the blood glucose level recorded from the initial value up to the 24 hours observation period. Upon oral administration of the extract D. philippinensis, the blood glucose level lowered by
$15.92 \%$ at $30 \mathrm{mins}, 5.57 \%$ at $120 \mathrm{mins}$ and $12.43 \%$ after 24 hours observation period. The positive control glibenclamide had percentage mean values lowered by $4.88 \%$ at $30 \mathrm{mins}, 15.5 \%$ at $120 \mathrm{mins}$ and $5.8 \%$ at 24 hours respectively. The percentage blood glucose level of $C$. variegatum and H. vulgaris consistently increased from initial value up to the 24 hours period of observation. Despite the decrease in blood glucose levels, all treatment groups failed to reach the normal blood glucose level. On a separate treatment set up constituting of normal mice, comparison revealed that diabetic group failed to reach the normal blood glucose level range of 120-123 $\mathrm{mg} / \mathrm{dl}$ recorded in normal mice up to 24 hours treatment period.

Phytochemicals known to be contained in D. philippinensis such as alkaloids, saponins, phenols, flavonoids and tannins [17] are known to decrease blood glucose aside from the additional anti-diabetic action of mineral and trace elements present such as zinc (Zn), Chromium (Cr), manganese $(\mathrm{Mn})$, selenium (Se), Potassium (K), Vanadium (V) and Calcium [18]. D. philippinensisis reported to possess several bioactive compounds which are of potential use against diabetes [19]. Although there are no reported studies on the antidiabetic potential of the bark of $D$. philippinensis, research on the ethanol leaf 
extracts indicate its hypoglycemic activity due to the presence of compounds such as tannins and flavonoids [20]. Flavonoids such as polyhydroxylated flavonol and myricetin have insulin omimetic properties that stimulate lipogenesis and transport of glucose in the adipocytes, hence, have potential on decreasing the blood sugar levels [21]. On the other hand, all forms of tannins, in clinical terms, may participate in the management of blood sugar level. This is demonstrated to stimulate the receptor cells to utilize carbohydrates [22] and are also described as polyphenolic compounds commonly found in both gymnosperms and angiosperms [23] hence, usually occur in almost all parts of a plant species, particularly in the bark, leaves, fruits and roots [24] and can be extracted through aqueous extraction. The possible presence of tannins in D. philippinensis bark may have contributed to its antidiabetic potential. As such, D. philippinensis extract should be evaluated to further confirm its active components and its bioactivities.

The mode of plant extraction may have also affected the effectivity of the plants on the antidiabetic potential testing. To mention, compounds with possible antidiabetic properties such as valuable secondary metabolites alkaloids, terpenes and flavonoids [25] [26] [27] which are reportedly produced by $C$. variegatum may not have been extracted through the water extraction method. Extraction of phytochemicals such as flavonol, terpenoids and alkaloids [28] may be improved by using another extraction solvent such as ethanol. Aqueous extraction methods, although shown to have similar efficiency as ethanol [29], may not have been as efficient in extracting the compounds present in $C$. variegatum, hence, showing negative results . In addition, alkaloids are important compounds due to its blood sugar lowering effect [30] but these can only be extracted through the ethanol extraction method. Phytochemicals in H. vulgaris such as saponins [31] have been demonstrated to decrease blood sugar levels in elderly diabetic patients [32] and reported to have antidiabetic effect [17]. However, this study revealed that $H$. vulgaris has no significant effect on the lowering of blood glucose level on diabetic mice. For some reason, saponins aside from possessing antimicrobial activity, its toxic effects may explain why this compound do not possess medicinal significance [33]. Also in some cases, because saponins possess carbohydrate moieties, this compound is capable of promoting further increase in the blood glucose level [34]. 
Table 1: Mean change in blood glucose level (mg/dl) recorded at $30 \mathrm{mins}, 120$ mins and 24 hours upon treatment administration

\begin{tabular}{cccc} 
Treatments & $\begin{array}{c}\text { After } 30 \\
\text { mins }\end{array}$ & After 120 mins & After $24 \mathrm{hrs}$ \\
\hline Negative Control & $-3.00 \mathrm{~b}$ & $-14.00 \mathrm{~b}$ & $-15.00 \mathrm{~b}$ \\
\hline Positive Control & $28.00 \mathrm{a}$ & $89.00 \mathrm{a}$ & $33.33 \mathrm{a}$ \\
\hline D. philippinensis & $77.67 \mathrm{a}$ & $\mathbf{2 7 . 6 7 a b}$ & $60.67 \mathrm{a}$ \\
C. variegatum & $-28.33 \mathrm{~b}$ & $-20.33 \mathrm{~b}$ & $-40.33 \mathrm{~b}$ \\
H. vulgaris & $-52.00 \mathrm{~b}$ & $-72.00 \mathrm{~b}$ & $-64.33 \mathrm{~b}$
\end{tabular}

*Means with similar letters per columns are not significantly different at $5 \%$ level of significance; Negative value indicates an increase in blood glucose level; Positive value indicates effectivity on the lowering of blood glucose level.

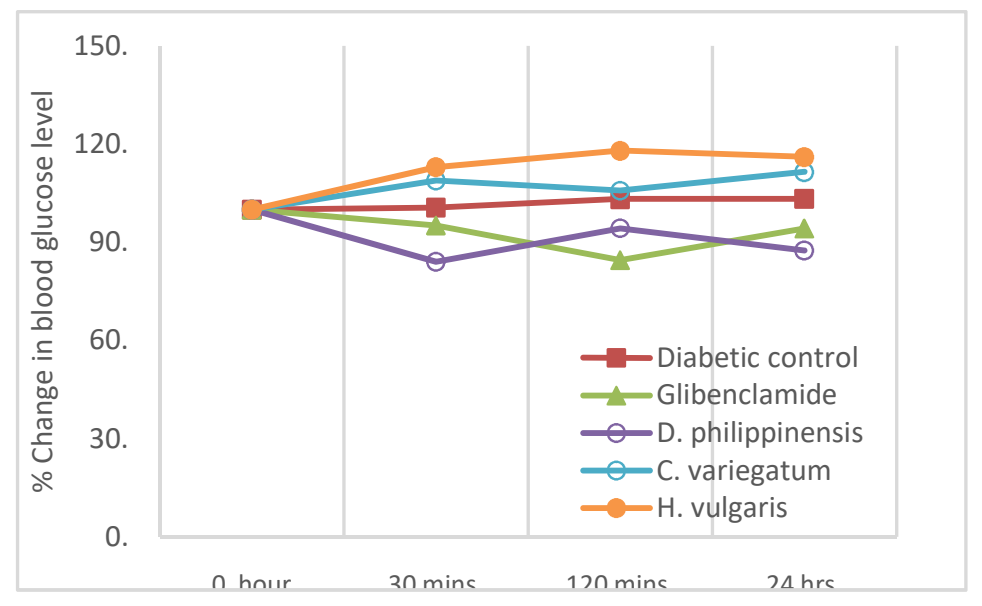

Figure 1: Mean percentage change of blood glucose levels (mg/dl).

\section{CONCLUSION}

D. philippinensis bark lyophilized plant extract possesses antidiabetic potential. The extract shows consistent effectivity in lowering the blood glucose level of the diabetic mice up to the 24 hours.

\section{ACKNOWLEDGEMENT}

The authors acknowledge the permission, assistance and support of the Ilongot-Eǵongot community of Bayanihan, Maria Aurora, Aurora, Philippines. This piece of work is dedicated to them. The authors acknowledge the support of the College of Veterinary Science and Medicine-
Animal Medical Center, Central Luzon State University, Science City of Munoz, Nueva Ecija, Philippines for the use of their laboratories.

\section{REFERENCES}

[1] PATIL, A., JADHAV, V., ARVINDEKAR, A. \& MORE, T. (2014). Antidiabetic Activity of Maesa indica (Roxb.) Stem Bark in Streptozotocin Induced Diabetic Rats. American Journal of Phytomedicine and Clinical Therapeutics, 4, 14-16.

[2] KANE, M.P., ABU-BAKER, A. \& BUSCH, R.S. (2005). The Utility of 
Oral Diabetes Medications in Type 2

Diabetes of the Young. Current

Diabetes Reviews, (1)1, 83-92.

[3] BAHMANI, M., ZARGARAN, A.,

KOPAEI, M.R. \& SAKI, K. (2014).Ethnobotanical Study of Medicinal Plants Used in the Management of Diabetes Mellitus in the Urmia, Northwest Iran. Asian Pacific Journal of Tropical Medicine, 7(1), 348-354.

[4] HAWKINS, B. (2008). Plants for Life:

Medicinal Plant Conservation and Botanic Gardens. United Kingdom Botanic Gardens Conservation International, 49, 1-3.

[5] BAHMANI, M., ZARGARAN, A., KOPAEI, M.R. \& SAKI, K. (2014). Ethnobotanical Study of Medicinal Plants Used in the Management of Diabetes Mellitus in the Urmia, Northwest Iran. Asian Pacific Journal of Tropical Medicine, 7(1), 348-354.

[6] BALOGUN, F.O., TSHABALALA, N.T. \& ASHAFA, A.T. (2016). Antidiabetic Medicinal Plants Used by the Basotho Tribe of Eastern Free State: A Review. Journal of Diabetes and Research, 16, 112-116.

[7] BABU, P.A., SUNEETHA, G., BODDEPALLI, R., LAKSHMI, V.V., RANI, T.S., RAMBABU, Y. \& SRINIVAS K. (2006). A Data Base of
389 Medicinal Plants for Diabetes. Bioinformation, 4, 130-171.

[8] YADAV, M., KHAN, K.K. \& BEG, M.Z. (2012). Medicinal Plants Used for the Treatment of Diabetes by the Baiga Tribe Living in Rewa District. Indian Journal and Literature Sciences, 2(1), 99-102.

[9] BALBERONA, A.N., NOVENO, J., ANGELES, M.G., SANTOS, R., CACHIN, E.J. \& JUDAN CRUZ, K. (2018). Ethnomedicinal Plants Utilized by the Ilongot-Eǵongot Community of Bayanihan, Maria Aurora, Aurora, Philippines. International Journal of Agricultural Technology. 4, 1-6.

[10] INSTITUTIONAL ANIMAL CARE AND USE COMMITTEE (IACUC) GUIDEBOOK. 2002. Office of Laboratory Animal Welfare and Applied Research Ethics National Association. Marky Pitts, Ed. 2nd ed.

[11] KALIWAL, B.B., SHETTI, A.A. \& SANAKAL, R.D. (2012). Antidiabetic Effect of Ethanolic Leaf Extract of Phyllanthus amarus in Alloxan-Induced Diabetic Mice. Pelagia Research Library, 2(1), 1115.

[12] SZKUDELSKI, T. (2001). The Mechanism of Alloxan and Streptozotocin Action In B-Cells of the Rat Pan- 
creas. Physiology Research, 50, 536546.

[13] SHARMA, B., SIDDIQUI, M.S., RAM, G., YADAV, R.K., KUMARI, A., SHARMA, G. \& JASUJA, N.D. (2014). Rejuvenating of Kidney Tissues on Alloxan-Induced Diabetic Mice Under the Effect of Momordica charantia. Advances in Pharmaceutics, 14, 4-5.

[14] ABDIRAHMAN, Y.A., JUMA, K.K., MUKUNDI, M.J., GITAHI, S.M., AGYIRIFO, D.S., NGUGI, M.P., GATHUMBI， P.K., NGERANWA, J.J. \& NJAGI, E.N. (2015). In-Vivo Antidiabetic Activity and Safety of the Aqueous Stem Bark Extract of Kleinia squarrosa. Journal of Diabetes and Metabolism, 6(9), 1-7.

[15] ARIKA, W.M., ABDIRAHMAN, Y.A., MAWIA, M.A., WAMBUA, K.F., NYAMAI, D.M., OGOLA, P.E., KIBOI, N.G., NYANDORO, H.O., AGYIRIFO, D.S., NGUGI, M.P. \& NJAGI, E.N. (2015). In Vivo Antidiabetic Activity of the Aqueous Leaf Extract of Croton macrostachyus in Alloxan Induced Diabetic Mice. Pharmaceutica Analytica Acta, 6, 11.

[16] NJAGI, J.M., NGUGI, M.P., KIBITI, C.M., NGERANWA, J., NJUE, W., GATHUMBI, P. \& NJAGI, E. (2015). Hypoglycemic Effect of $\mathrm{He}$ - lichrysum odoratissimum in AlloxanInduced Diabetic Mice. Journal of Phytopharmacology, 4(1), 30-33.

[17] KIMANI, N.L., NJANGIRU, I.K., NJAGI，E.N.M. \& ORINDA，G.O. (2017). Antidiabetic Activity of Administration of Aqueous Extract of Berberis holstii. Journal of Diabetes and Metabolism, 8, 774.

[18] PIERO, M.N., NJAGI, J.M., KIBITI, C.M., NGERANWA, J.J.N. \& NJAGI, E.N.M. (2012). Metabolic Complications of Diabetes Mellitus: A Review. Southeast Asian Journal of Biological Sciences, 2, 37-49.

[19] MACAHIG, R.S., MATSUNAMI, K. \& OTSUKA, H. (2011). Chemical Studies on an Endemic Philippine Plant: Sulfated Glucoside and secoA-Ring Triterpenoids from Dillenia philippinensis. Chemical and Pharmacological Bulletin, 59(3), 397401.

[20] MARTILLANA, M.R., ARTIFICIO, T.L., NOLASCO, G.R., PARCO, A. \& SANTOS, P.C. (2014). AntiHyperglycemic Effects of Dillenia philippinensis Rolfe. (Dilleniaceae) Crude Leaf Extract on Hyperglycemic Mice. Research Gate, 8, 1-89.

[21] MODAK, M., DIXIT, P., LONDHE, J., GHASKADBI, S. \& DEVESA- 
GAYAM, T.A. (2007). Indian Herbs and Herbal Drugs Used for the Treatment of Diabetes. Journal of Clinical Biochemistry and Nutrition, 40(3), 163-173.

[22] KUMARI, M., JAIN, S. \& DAVE, R. (2014). Babul (Acacia nilotica): A Potential Source of Tannin and its Suitability in Management of Type II Diabetes. Nutrition \& Food Science, 2, 122-124.

[23] HOFMANN, S. \& BROWNLEE, M. (2004). Biochemistry and Molecular Cell Biology of Diabetic

Complications: A Unifying

Mechanism. Philadelphia Lippincott Williams \& Wilkins, 8, 1441-1456.

[24] MAKKAR, H.P. (2003). Quantification of Tannins in Tree and Shrub Foliage: A Laboratory Manual. Dordrecht: Kluwer Academic Publishers, 7, 1-413.

[25] PUEBLA, P., LOPEZ, J.L., GUERRERO, M., CARRON, R., MARTIN, M.L., ROMAN, L.S. \& FELICIANO, A.S. (2003). Neo-Clerodane Diterpenoids from Croton schiedeanus. Phytochemistry, 6(2), 551-554.

[26] MACIEL, A.M., PINTO, A.C., BRABO, S.N. \& SILVA, M.N. (1998). Terpenoids from Croton cajura. Phytochemistry, 49, 823-826.
[27] MARTINS, A.P., SALGUEIRO, L.R., CONCLAVES, M.J., VILA, R., TOMI, F., ADZET, T., CUNHA, A.P., CANIGUERAL, S. \& CASANOVA, J. (2002). Antimicrobial Activity and Chemical Composition of Bark Oil of Croton stellulifer. Planta Medica, 66, 647-652.

[28] SELVAMUTHUKUMARAN, M. \& SHI, J. (2017). Recent Advances in Extraction of Antioxidants from Plant By-Products Processing Industries. Food Quality and Safety, 1, 6181.

[29] AZWANIDA, N.N. (2015). A Review on the Extraction Methods Use in Medicinal Plants, Principle, Strength and Limitation. Medicinal and Aromatic Plants, 2(4), 196.

[30] TIONG, S.H., LOOI, C.Y., HAZNI, H., ARYA, A. \& PAYDAR, M. (2013). Antidiabetic and Antioxidant Properties of Alkaloids from Catharanthus roseus (L.). Molecules, 18, 9770-9784.

[31] MORILLA, L.J., SUMAYA, N.H., RIVERO, H. \& MADAMBA, R.S. (2014). In Vitro Propagation of Croton (Codiaeum Variegatum). International Conference on Food, Biological and Medical Sciences, 5, 11-17. 
[32] CHEN, K.J. \& ZHANG, W.P. (1987). Advances on Anti-ageing Herbal Medicines in China. Abstracts of Chinese Medicine, 1, 309-330.

[33] MACIEL, A.M., PINTO, A.C., BRABO, S.N. \& SILVA, M.N. (1998).
Terpenoids from Croton cajura. Phytochemistry, $49,823-826$.

[34] HOSTETTMANN, K. \& MARSTON, A. (2005). Saponins and Alkaloids: Nature's Curse or Blessing. Journal of Chemistry and Science, 11, 1-5. 